\title{
Lisianthus Growth and Flowering Responses to Uniconazole
}

\section{Terri Woods Starman \\ Department of Plant and Soil Science, Southern Illinois University, Carbondale, IL 62901}

Additional index words. ancymidol, daminozide, Eustoma grandiflorum, plant growth retardant, Lisianthus russellianus, prairie gentian, XE-1019

\begin{abstract}
One and two foliar spray and single-drench applications of uniconazole were applied to Eustoma grandiflorum (Raf.) Shinn (lisianthus) 'Yodel Blue' to determine optimal concentrations for potted plant height control. A single uniconazole spray at $10.0 \mathrm{mg} \cdot$ liter $^{-1}$ applied 2 weeks after pinching, two uniconazole applications at 5.0 mg.liter ${ }^{-1}$ applied 2 and 3 weeks after pinching, or a drench at $1.60 \mathrm{mg}$ a.i. per pot applied 2 weeks after pinching gave equally good height control. At these concentrations, uniconazole was similar in its effect on plant height to daminozide foliar sprays at 7500 and $2500 \mathrm{mg} \cdot \mathrm{liter}^{-1}$ applied once and twice, respectively. Drenching with uniconazole at $1.60 \mathrm{mg}$ a.i. per pot did not increase days to flower (DTF), whereas foliar spray applications did. Drenching did not reduce flower size, but increased flower number at time of harvest. Chemical names used: $\alpha$-cyclopropyl- $\alpha$-(4-methoxyphenyl)5-pyrimidinemethanol (ancymidol); butanedioic acid mono(2,2-dimethylhydrazide) (daminozide);(E)-(S)-1-(4-chlorophenyl)-4,4-dimethyl-2-(1,2,4-triazol-1-yl)-pent-1-ene3-01 (uniconazole).
\end{abstract}

Hybridized in Japan and returned to its native North America as a cut flower and potted plant (Rob and Lawson, 1984), lisianthus, or the prairie gentian, "has gained widespread appeal due to its beauty and flower longevity.

Whether lisianthus is best grown as a cut flower or potted plant is debatable. The long, straight stems make lisianthus seem best-suited as a cut flower; however, cut-flower production peaks in the summer and requires a long growing period, factors that limit overall productivity (Halevy and Kofranek, 1984). As a potted plant, lisianthus is high-temperature tolerant (Tjia and Jierwiriyapant, 1987), produces long-lasting flowers, and blooms up to 5 weeks (Rob and Lawson, 1984). Potted plants can also be transplanted into the annual garden (Parke, 1986). However, lisianthus grows 50 to $75 \mathrm{~cm}$ tall (Rob and Lawson, 1984) and must be treated with a growth retardant to produce a quality potted plant.

Received for publication 19 Mar. 1990. I thank Paul Gibson, Dept. of Plant and Soil Science, Southern Illinois Univ., for assistance in data analysis, and Barbara Garrison for technical assistance. The cost of publishing this paper was defrayed in part by the payment of page charges. Under postal regulations, this paper therefore must be hereby marked advertisement solely to indicate this fact.
Five growth regulators have been reported to be effective for controlling height of potted lisianthus. Ancymidol drench (0.25 and $0.30 \mathrm{mg}$ a.i. per 1.8-liter pot) or foliar spray (66 mg.liter ${ }^{-1}$ ) and daminozide foliar spray reported to give good height control of various lisianthus cultivars (Halevy and Kofranek, 1984; Klingaman, 1984; Tjia and Sheehan, 1986; Wobbe and "Campbell, 1986). Ethephon foliar spray (500 mg.liter ${ }^{-1}$ ) has also been found to reduce height of lisianthus potted plants (Wobbe and Campbell, 1986). Paclobutrazol drench $(0.20 \mathrm{mg}$ a.i. per 8.9 $\mathrm{cm}$ pot) controlled lisianthus height (Adriansen, 1989), whereas chlormequat drenches at $0.09,0.18$, or $0.36 \mathrm{~g} / 10-\mathrm{cm}$ pot (Tjia and Sheehan, 1986) or $0.30 \mathrm{~g} / 15$-cm pot (Halevy and Kofranek, 1984) were found to be ineffective. Uniconazole was found to be effective on lisianthus (Tjia and Jierwiriyapant, 1987), but rates were not reported.

The objective of this research project was to determine the optimal concentration of uniconazole foliar spray and medium drench and to compare the effectiveness of uniconazole with conventional growth retardants for controlling lisianthus plant height when grown as a potted plant.

Seeds of lisianthus 'Yodel Blue' (Ball Seed, West Chicago, Ill.) were sown 22 Jan. 1988 in rows in bedding plant flats containing Jiffy $\left(2500,5000\right.$, or $7500 \mathrm{mg} \cdot$ liter $\left.^{-1}\right)$ have been
Mix (Jiffy Products of America, West Chicago). The flats were placed under intermittent mist until germination on 2 Feb. When seedlings had developed their third true leaf (7 Mar.), they were transplanted to cell packs (48 cells per flat) containing ProMix BX (Premier Brands, New Rochelle, N.Y.). Seedlings were shaded for 1 week following transplanting. On $20 \mathrm{Apr}$., four seedlings each were transplanted into 1.8 -liter $(15-\mathrm{cm}$ diameter) plastic pots in the same medium. Plants were graded for uniformity before transplanting and were pinched manually above the third node on 6 May. Plants were grown in a 24/18C (venting/night temperature set points) glass greenhouse in full sun and fertilized at each irrigation with $20 \mathrm{~N}$ $4.4 \mathrm{P}-16.6 \mathrm{~K}$ with $\mathrm{N}$ at $100 \mathrm{mg} \cdot$ liter $^{-1}$ until final transplanting and $300 \mathrm{mg} \cdot$ liter $^{-1}$ thereafter.

When axillary shoots had developed to 3.8 to $5 \mathrm{~cm}$ (18 May), growth retardant treatments were applied. These included uniconazole applied as a foliar spray at $204 \mathrm{ml}$ of solution sprayed evenly over $1 \mathrm{~m}^{2}$ of bench space. At treatment time, the plant canopy diameter was $17.8 \mathrm{~cm}$ and therefore each pot received a spray volume of $\approx 5 \mathrm{ml}$. Concentrations of uniconazole included $0,2.5,5.0$, 10.0 , and $20.0 \mathrm{mg} \cdot$ liter $^{-1}$ applied once or twice with the second application occurring 1 week following the first (25 May). Other uniconazole treatments were applied in a 125 $\mathrm{ml} /$ pot medium drench at $0,0.20,0.40,0.80$, or $1.60 \mathrm{mg}$ a.i. per pot. Ancymidol treatments were $66 \mathrm{mg} \cdot$ liter $^{-1}$ foliar spray to runoff and $0.25 \mathrm{mg}$ a.i. per pot drench applied in $178 \mathrm{ml}$ water per pot. The different volumes were used to conform to label recommendations. Treatments with daminozide were foliar spray to runoff at $7500 \mathrm{mg} \cdot \mathrm{liter}^{-1}$ applied once and $2500 \mathrm{mg} \cdot$ liter $^{-1}$ applied twice at a 1-week interval. All drench treatments were applied coincidentally with the initial foliar spray treatments, but on separate plants. Plants were harvested 24 weeks after sowing (29 June) at the scheduled time (20 to 25 weeks after sowing) required to produce a marketable crop according to commercial guidelines (Ball Seed).

Data taken at harvest included plant height calculated as the average height of the four plants per pot determined by cutting the stem at medium line and measuring from the cut end to the stem apex. Other growth measurements included total leaf and plant fresh weight and plant dry weight of all plants within a pot. Fresh weight measurements were made gravimetrically immediately after harvest and dry weights followed $72 \mathrm{hr}$ at $80 \mathrm{C}$. 
Table 1. Effects of the growth retardants ancymidol, daminozide, and uniconazole on lisianthus plant characteristics.

\begin{tabular}{|c|c|c|c|c|c|c|c|}
\hline Treatment & $\begin{array}{c}\text { Plant ht } \\
(\mathrm{cm})\end{array}$ & $\begin{array}{c}\text { Fresh wt } \\
(\mathrm{g})\end{array}$ & $\begin{array}{c}\text { Dry wt } \\
(\mathrm{g})\end{array}$ & $\begin{array}{c}\text { Days } \\
\text { to } \\
\text { flower }\end{array}$ & $\begin{array}{c}\text { Flowers } \\
\text { (no.) }\end{array}$ & $\begin{array}{l}\text { Buds } \\
\text { (no.) }\end{array}$ & $\begin{array}{l}\text { Petal } \\
\text { length } \\
(\mathrm{cm})\end{array}$ \\
\hline \multicolumn{8}{|l|}{ Uniconazole } \\
\hline \multicolumn{8}{|l|}{ Foliar spray $\left(\mathrm{mg} \cdot \mathrm{liter}^{-1}\right)$} \\
\hline \multicolumn{8}{|l|}{ One application } \\
\hline 0.0 & 51.1 & 193 & 31.7 & 154 & 3.1 & 16.6 & 6.2 \\
\hline 2.5 & 43.0 & 177 & 27.5 & 154 & 2.8 & 15.9 & 6.3 \\
\hline 5.0 & 41.2 & 172 & 26.0 & 155 & 2.7 & 16.6 & 6.0 \\
\hline 10.0 & 31.6 & 150 & 22.3 & 157 & 2.2 & 18.7 & 6.0 \\
\hline 20.0 & 26.3 & 141 & 19.5 & 159 & 2.6 & 17.6 & 5.5 \\
\hline \multicolumn{8}{|l|}{ Two applications } \\
\hline 0.0 & 52.8 & 194 & 32.6 & 153 & 3.8 & 16.8 & 6.0 \\
\hline 2.5 & 38.5 & 170 & 25.4 & 155 & 2.9 & 18.4 & 6.2 \\
\hline 5.0 & 29.2 & 142 & 20.3 & 156 & 1.8 & 17.6 & 5.9 \\
\hline 10.0 & 25.4 & 149 & 21.0 & 158 & 2.6 & 21.8 & 5.1 \\
\hline 20.0 & 20.6 & 129 & 17.8 & 156 & 1.7 & 23.1 & 4.6 \\
\hline \multicolumn{8}{|l|}{ Medium drench (mg a.i./pot) } \\
\hline 0.00 & 51.1 & 202 & 34.3 & 156 & 2.4 & 18.3 & 6.2 \\
\hline 0.20 & 49.1 & 210 & 33.0 & 157 & 2.5 & 20.0 & 6.3 \\
\hline 0.40 & 43.2 & 177 & 29.0 & 155 & 3.7 & 16.9 & 6.0 \\
\hline 0.80 & 37.1 & 181 & 28.0 & 156 & 3.9 & 17.5 & 6.0 \\
\hline 1.60 & 32.0 & 173 & 25.8 & 152 & 5.3 & 15.7 & 6.3 \\
\hline \multicolumn{8}{|l|}{ Ancymidol } \\
\hline Foliar spray $\left(66 \mathrm{mg} \cdot \mathrm{liter}^{-1}\right)$ & 38.4 & 178 & 27.0 & 154 & 4.4 & 15.1 & 5.9 \\
\hline Medium drench $(0.25 \mathrm{mg}$ a.i./pot) & 46.7 & 187 & 29.6 & 154 & 3.6 & 14.8 & 6.3 \\
\hline \multicolumn{8}{|l|}{ Daminozide } \\
\hline \multicolumn{8}{|l|}{ Foliar spray $\left(\mathrm{mg} \cdot \mathrm{liter}^{-1}\right)$} \\
\hline 7500 , once & 30.5 & 176 & 25.6 & 158 & 2.2 & 19.7 & 5.6 \\
\hline 2500 , twice & 28.9 & 157 & 23.1 & 159 & 1.9 & 17.5 & 5.5 \\
\hline \multicolumn{8}{|l|}{ Contrasts } \\
\hline Treatment effect & $* * *$ & $* * *$ & $* * *$ & $* * *$ & $* * *$ & $* * *$ & $* * *$ \\
\hline \multicolumn{8}{|l|}{ One spray uniconazole } \\
\hline Linear & $* * *$ & $* *$ & **** & ** & NS & NS & $* * *$ \\
\hline Quadratic & $* * *$ & NS & NS & NS & NS & NS & NS \\
\hline Cubic & NS & NS & NS & NS & NS & NS & NS \\
\hline Quartic & NS & NS & NS & NS & NS & NS & NS \\
\hline \multicolumn{8}{|l|}{ Two spray uniconazole } \\
\hline Linear & $* * *$ & $* * *$ & $* * *$ & NS & ${ }^{*}$ & $* * *$ & $* * *$ \\
\hline Quadratic & $* * *$ & NS & $* *$ & $*$ & NS & NS & NS \\
\hline Cubic & $* * *$ & NS & * & NS & NS & NS & *** \\
\hline Quartic & NS & NS & NS & NS & NS & NS & NS \\
\hline \multicolumn{8}{|l|}{ Uniconazole drench } \\
\hline Linear & $* * *$ & * & ** & ** & $* * *$ & * & NS \\
\hline Quadratic & ** & NS & NS & NS & NS & NS & * \\
\hline Cubic & NS & NS & NS & NS & NS & NS & NS \\
\hline Quartic & NS & NS & NS & NS & NS & NS & NS \\
\hline Ancymidol vs. daminozide & $* * *$ & NS & * & $* * *$ & ** & ** & $* * *$ \\
\hline
\end{tabular}

Treatment effect or contrast nonsignificant or significant at $0.05 \geq \alpha \geq 0.01,0.01 \geq \alpha>$ 0.001 , or $\alpha \leq 0.001$, respectively.

Days to flower (DTF) was determined as the number of days from seed sowing until the first flower within a pot opened, i.e., the corolla flared, exposing pistil and stamens. Flower and bud number and petal length were measured on each plant within a pot and the measurements averaged together. Flower number was a count of all open flowers and bud number was all unopened flowers (corolla twisted and petal apices touching). Petal length was measured from the base of the receptacle to the apex of the petals.

The experiment consisted of 19 treatments using 10 One-pot replicates and a completely randomized design. Data were subjected to one-way analysis of variance and single-degree-of-freedom contrasts were conducted for appropriate comparisons. Analogous controls were included in the trend analysis as zeros. Orthogonal polynomial coefficients were obtained from a table of unequally spaced treatment coefficients (Little and Hills,
1978). Variables where measurements were taken per plant were analyzed similarly using plants as subsamples and pots within treatments as the error term. The experiment was a modified (i.e., with the addition of a wider range of concentrations) replication of a 1987 experiment in which similar results were obtained.

Growth retardant treatments reduced plant height compared to controls (Table 1). The height of plants treated with either a single foliar spray or drench of uniconazole decreased quadratically with increased concentration. With two spray applications the trend was cubic. Daminozide exceeded ancymidol in retarding plant height. Based on the standard 1.5 to 2 times the container height guideline used to produce a quality plant (Sachs et al., 1976), plant height should be 22.5 to $30.0 \mathrm{~cm}$ in a $15-\mathrm{cm}$ pot. Plant heights following uniconazole foliar sprays at 10 and $20 \mathrm{mg} \cdot \mathrm{liter}^{-1}$ applied once or 5 and 10 mg.liter ${ }^{-1}$ applied twice or drench application at $1.60 \mathrm{mg}$ a.i. per pot did not differ from those following daminozide treatments as determined by $t$ tests conducted between pairs of means. The only exception was that two foliar spray applications of uniconazole at $10 \mathrm{mg} \cdot$ liter $^{-1}$ reduced height compared to one application of daminozide at 7500 $\mathrm{mg} \cdot \operatorname{liter}^{-1}(t=2.15, P=0.05)$.

All uniconazole application methods resulted in linear trends of decreasing fresh weights with increasing concentration (Table 1). Reductions in dry weights were linear with increasing concentration for single foliar spray and drench applications, and cubic for 2-spray applications. Daminozide-treated plants did not differ in fresh weight but had decreased dry weight compared to ancymidol-treated plants. Leaf fresh weight was not affected by growth retardants (data not shown).

DTF responded linearly to uniconazole as a single foliar spray or as medium drench application, with DTF increasing with increasing spray concentration but decreasing with increasing drench concentration (Table $1)$. The response was quadratic with twospray applications. A uniconazole drench at $1.60 \mathrm{mg}$ a.i. per pot reduced DTF relative to the control, but lower concentrations did not. Daminozide treatments delayed DTF compared to ancymidol treatments.

One-spray uniconazole applications did not influence the number of flowers or buds (Table 1). Two uniconazole spray applications linearly decreased flower number but increased that of buds as concentration increased. Conversely, increased concentrations of uniconazole drench treatments resulted in a linear increase in flower number and a decrease in bud number. Ancymidol-treated plants had more flowers and fewer buds than daminozide-treated plants.

Petal length tended to be reduced linearly with increased foliar spray concentrations when uniconazole was applied once (Table $1)$. The trend was cubic with two-spray applications and quadratic with uniconazole drenches. High drench rates did not reduce petal length compared to controls. Daminozide treatments reduced petal length compared to ancymidol.

Uniconazole was an effective growth retardant for controlling plant height of lisianthus. From the results of this experiment, uniconazole spray application at 10.0 $\mathrm{mg} \cdot \mathrm{liter}^{-1}$ applied once, or $5.0 \mathrm{mg} \cdot \mathrm{liter}^{-1}$ applied twice or drench application at 1.60 $\mathrm{mg}$ a. i. per pot is recommended. Concentrations of $20.0 \mathrm{mg} \cdot$ liter $^{-1}$ applied once and $10.0 \mathrm{mg} \cdot$ liter $^{-1}$ applied twice gave good height control and were more effective than the lower concentrations in preventing lodging, but were considered excessive because reduction in peduncle length caused undesirable crowding of flowers. Uniconazole foliar sprays were more effective than medium drenches in reducing overall size of lisianthus plants as measured by fresh and dry weight.

Uniconazole foliar sprays at the higher concentrations tested delayed DTF of lisian- 
thus plants, whereas drenching did not; the high drench concentration actually hastened blooming by $\approx 4$ days. Growth retardants have indirectly influenced flowering by retarding vegetative growth of other floricultural crops (Larson, 1985). Growth retardants promote flower bud initiation in some crops and flower bud development in others (Larson, 1985).

Delayed DTF with reduced petal length of foliar spray-treated plants relative to those exposed to the drench may indicate that uniconazole sprays affected cell elongation and/or division during flower development to a greater extent than when the chemical is applied to plant roots by drenching.

Another opposing effect of uniconazole drench and spray application was the effect on flower and bud number. Plants treated with a drench had more flowers and fewer buds as concentration increased. The opposite was true with two foliar spray applications. This effect may have been due to earlier maturity (as measured by DTF) of the drenched plants since all treatments were harvested the same day. However, flower and bud number of plants that received one uniconazole foliar spray did not' differ significantly from those of the controls even though they were delayed in DTF.

The uniconazole concentrations recommended as above were similar in their effect on plant height to daminozide. These, in turn, more effectively controlled height than ancymidol. However, ancymidol did not delay flowering or reduce flower number and size to as great an extent as daminozide. Tjia and Sheehan (1986) did not find a delay in flowering with ancymidol or daminozide treatments. Halevy and Kofranek (1984) found that ancymidol advanced flowering 10 days and daminozide delayed flowering when plants-were grown at $13 \mathrm{C}$, but not at $18 \mathrm{C}$. In another study, daminozide and ancymidol both delayed flowering 10 to 14 days (Wobbe and Campbell, 1986). These diverse responses, possibly due to geographical area and cultivar specificity, necessitate adequate testing of growth retardants when recommendations for growers are developed.

\section{Literature Cited}

Adriansen, E. 1989. Eustoma is ideal for pots. Greenhouse Grower 7(4):50-54.

Halevy, A.H. and A.M. Kofranek. 1984. Evaluation of lisianthus as a new flower crop. HortScience 19:845-847.

Klingaman, G.L. 1984. Eustoma grandiflorum a progress report on work conducted in Arkansas. HortScience 19:201. (Abstr.)

Larson, R.A. 1985. Growth regulators in floriculture. Hort. Rev. 7:399-481.

Little, T.M. and F.J. Hills. 1978. Agricultural experimentation: Design and analysis. Wiley, New York.

Parke, M. 1986. The new look of lisianthus. Horticulture $\operatorname{LXIV(3):32-34.~}$

Rob, M.S.M. and R.H. Lawson. 1984. The lure of lisianthus. Greenhouse Manager 5:103-104, 108, 110, 112-114, 116-119, 121.

Sachs, R.M., A.M. Kofranek, and W.P. Hackett. 1976. Evaluating new pot plant species. Florists Rev. 159(4116):35-36, 80-84.
Tjia, B. and U. Jierwiriyapant. 1987. Give lisianthus a try. Greenhouse Grower 5(11):3840.

Tjia, B. and T.J. Sheehan. 1986. Chemical height control of Lisianthus russellianus. HortScience
21:147-148.

Wobbe, S. and F.J. Campbell. 1986. The effect of growth regulators on Lisianthus (Eustoma grandiflorum). Floralert 1:1-4. 